\title{
Who Cares for Agile Work? In/Visibilized Work Practices and Their Emancipatory Potential
}

\author{
Alev Coban · Klara-Aylin Wenten
}

Received: 29 February 2020 / Accepted: 3 February 2021 / Published online: 23 April 2021

(C) The Author(s) 2021

\begin{abstract}
The future of work has become a pressing matter of concern: Researchers, business consultancies, and industrial companies are intensively studying how new work models could be best implemented to increase workplace flexibility and creativity. In particular, the agile model has become one of the "must-have" elements for re-organizing work practices, especially for technology development work. However, the implementation of agile work often comes together with strong presumptions: it is regarded as an inevitable tool that can be universally integrated into different workplaces while having the same outcome of flexibility, transparency, and flattened hierarchies everywhere. This paper challenges such essentializing assumptions by turning agile work into a "matter of care." We argue that care work occurs in contexts other than feminized reproductive work, namely, technology development. Drawing on concepts from feminist Science and Technology Studies and ethnographic research at agile technology
\end{abstract}

\footnotetext{
A. Coban $(\square)$

Department of Human Geography, Goethe-

University Frankfurt, Theodor-W.-Adorno-Platz 6,

60629 Frankfurt am Main, Germany

e-mail: coban@geo.uni-frankfurt.de

K.-A. Wenten

Munich Center for Technology in Society, Technical

University of Munich, Arcisstraße 21, 80333 Munich,

Germany

e-mail: Klara-Aylin.Wenten@tum.de
}

development workplaces in Germany and Kenya, we examine what work it takes to actually keep up with the imperative of agile work. The analysis brings the often invisibilized care practices of human and nonhuman actors to the fore that are necessary to enact and stabilize the agile promises of flexibilization, coworking, and rapid prototyping. Revealing the caring sociotechnical relationships that are vital for working agile, we discuss the emergence of power asymmetries characterized by hierarchies of skills that are differently acknowledged in the daily work of technology development. The paper ends by speculating on the emancipatory potential of a care perspective, by which we seek to inspire careful Emancipatory Technology Studies.

Keywords Agile work - Feminist science and technology studies · Matters of care · Emancipation · Background work

\section{Introduction: Working Agile as the New Imperative for Technology Development}

Today, the re-organization of work, especially spurred on by the agile work model, is a popular global trend in technology development. It includes the implementation of new tools to organize daily work tasks, the introduction of co-working areas, and access to prototyping machines such as 3D printers or laser cutters [1-3]. As opposed to previous more bureaucratic, slower, and depersonalized 
processes in technology development, the model of agile work promises to quickly develop a first prototype, to increase flexibility, and to generate greater interdisciplinary collaboration [4-6]. These pledges were first formalized, amongst others, by a group of software engineers who formulated the "Agile Manifesto for Software Development" [7] in 2001.

We regard the agile model as a new imperative of working as it has turned into one of the "must-have" elements of current attempts to re-organize work practices and technology development processes [8]. Various actors such as researchers, business consultancies, political institutions, and industrial companies are intensively studying how agile work models could be best integrated into innovation strategies and the organization of work [9-11]. Turner [12], for instance, shows how start-ups and technology companies have undergone processes in which "hierarchies have been replaced by flattened structures, long-term employment by short-term, project-based contracting, and professional positions by complex, networked forms of sociability" ([12], p. 239). More critical studies further emphasize how agile visions with originally emancipatory intents have been recuperated by capitalism [13-15], for example, how demands for less alienating and more self-determined work were translated into corporate structures and commercializable methods, tools, and machines. This is also the case in less institutionalized workplaces of technology development such as makerspaces ${ }^{1}$ that increasingly internalize commercial principles associated with the agile model. Once spaces for makers ${ }^{2}$ believing in the democratization of knowledge production by sharing technology, knowledge, and skills through digital means, makerspaces often turned to commercial, entrepreneurial, and agile practices [17, 18]. Thus, the implementation of flexible and collaborative workplaces, where workers quickly produce prototypes, has gained global momentum, compelling

\footnotetext{
${ }^{1}$ Makerspaces are workshops that are accessible to those who are interested in producing, repairing or tinkering with the provided machine tools.

${ }^{2}$ Makers are individuals who gather within a community that shares similar interests in digital fabrication by using technologies such as 3D printers, laser cutters or other industrial machines. Maker communities are informed by different ideologies ranging from self-sufficiency, anti-capitalist production or democratized knowledge transfer on the one hand, and commercialization and entrepreneurialism on the other [16].
}

almost every working individual to follow and keep up with working agile.

What we observe is that the imperative to work agile goes together with strong presumptions regarding the agile model as an inevitable method with universal effects: Agile work appears to be a tool that can be universally integrated and applied to different workplaces while having the same outcomes of flexibility, collaborative work, and fast prototyping. We claim that perceiving agility as a necessity for societal progress and as a blueprint in varying workplaces reproduces power asymmetries, for example, the devaluation of ordinary routine practices [19] or the hierarchization between a putative center and periphery of innovation [20], rather than engaging with emancipatory change. Recent research on agile work is rich in studies on new forms of surveillance and control $[21,22]$ and the role of materiality in flexible work contexts [23]. However, these studies also treat the agile model as a given matter of fact, thereby accepting far too quickly its widespread persistence in technology development.

In this paper, we seek to extend studies on the agile re-organization of work by drawing on the concept of matters of care from feminist Science and Technology Studies (STS) scholar Puig de la Bellacasa [24] and challenge the universal and essentialist perspectives, promises, and demands circulating around the imperative of an agile workplace. Therefore, we turn agile work into a matter of care and examine what it takes to actually keep up with the imperative of agile work. Hence, and unlike recent studies on agile work, we foreground the diverse work practices that are often dismissed or perceived as running in the background but that are, in fact, essential requirements for the agile workplace. Moreover, we emphasize that the realization of working agile is not a social practice uniquely exercised by humans. Considering agile work as a complex, unstable sociotechnical assemblage $^{3}$, we highlight how agile work consists of caring relationships between human and nonhuman entities.

In the first part of the paper, we illustrate our theoretical foundations of care, affects, and embodied

\footnotetext{
${ }^{3}$ Regarding agile work as a sociotechnical assemblage means that human and non-human actors not only constitute the agile work environment, but at the same time are also constituted by it [25].
} 
work as mainly coming from a feminist STS perspective. The second part then draws empirical attention to what is cared for while new technology is being developed and innovated at agile workplaces. Our ethnographic research comprises several research stays at Kenyan makerspaces between 2015 and 2017 and at German industrial companies between 2016 and 2019. By focusing on the actual work carried out by technology developers at agile workplaces, we investigate the invisible everyday work to enact the promises of flexibilization, co-working, and rapid prototyping. We argue that agile work is only able to function due to the (often taken-for-granted) work of caring for its enactment and stabilization. The third part of the paper elaborates on power asymmetries, which we characterize as hierarchies of skills that are differently acknowledged in the daily work of agile actors. We conclude by speculating on the emancipatory potential of caring sociotechnical relationships that re-frame agile work from being merely a tool of efficiency to being a possibility of caring for one another without asymmetrical power dynamics.

\section{Matters of Care: Background Work and Affective Work}

The perspective on care illuminates the often-dismissed aspects of work happening in the background. Therefore, we use Puig de la Bellacasa's concept "matters of care" to analyze the inevitable work of enacting the sociotechnical assemblage of agile work. We draw on feminist STS and the sociology and geography of work and making to emphasize the importance of researching the affects and bodies at work in the context of technology development.

Feminist STS scholar Puig de la Bellacasa [24] expands on Latour's "matters of concern" [26], which exposes the knowledge politics of facts and their "staging" as concerns and, thus, as things ${ }^{4}$ that matter. Latour's matters of concern outline how facts are enacted and stabilized by their underlying politics, desires, and concerns. Yet both Puig de la Bellacasa and Latour seek to turn away from research that focuses on "notions of power, used as causal explanations [...] to undermine

\footnotetext{
${ }^{4}$ Both Puig de la Bellacasa and Latour understand "thing" as an issue or concern around which actors assemble - thus, a gathering that "brings people together" $[26,27]$.
}

what others present as facts" ([24], p. 88). According to Latour, these ready-made explanations would direct "one's attention toward the conditions that made [... facts] possible. However, this mean[s] accepting much too uncritically what matters of fact" are ([26], p. 231). Therefore, matters of concern emphasize that facts and things are highly vulnerable by investigating the different elements that constitute and stabilize them. We use this perspective to regard agile work as an imperative constituted by sociotechnical actors, different politics, and desires and argue that these different elements finally stage agile work as a public matter of fact and only render its (worldwide) persistence possible.

\section{Matters of Care and Background Work}

Despite applauding much of Latour's work, Puig de la Bellacasa argues for a research ethos that re-presents the concerns and sociotechnical assemblages as "matters of care." She proposes to conceptualize concerns as vulnerable and in need of care, based on her understanding of care as being "concomitant to life" and thus a "vital necessity" ([28], p. 198). Therefore, focusing on care is about the "dismissed labours of everyday maintenance of life" and aims at memorizing practices of exclusion and oppression ([24], p. 100). Criticizing Latour's tendency to moderate critical standpoints, Puig de la Bellacasa stresses the importance of "counting in participants and issues [...] whose modes of articulation indicate a politics that is 'imperceptible' within prevalent ways of understanding" ([24], pp. 94). For her, researching care practices does not mean looking at the problematics of (feminized) reproductive care work ${ }^{5}$ but, in a more general way, showing who or what is vulnerable and precarious. She explicitly includes care for both humans and non-humans and points out that care in the sense of "taking care" of sociotechnical assemblages "can be found in every context" ([24], p. 93). Thus, in line with Puig de la Bellacasa and the few studies on care in technology work such as IT security [33], water infrastructure maintenance [34], and scientific

\footnotetext{
5 There is a vast number of inspiring (feminist) research on care work pointing to the neglect of often female, unpaid and domestic work within hegemonic valuations of work [e.g. 29, 30]. Yet, in line with current STS research [31, 32], we transfer the notion of care to contexts that may not appear to be related to care work at first sight.
} 
data production [35], we argue for the existence and importance of sociotechnical care within technology development.

By relating such a care perspective to the subject of work, we detect the dismissed everyday work of enacting and stabilizing agile work, which constitutes the highly fragile and vulnerable sociotechnical assemblage. Star and Strauss call these dismissed but necessary work practices "background work" ([36], p. 20 ). It is usually work that is taken for granted or routinized while "the workers themselves are quite visible [in the workplace], yet the work they perform is invisible or relegated to a background of expectation" ([36], p. 15). Thus, following Law [37] who refers to Star's concept of "deleting of work" in organizations, the investigation of background work can bring power relations and struggles in the workplace to the fore front: The deletion of work mainly affects "the work of subordinates: to assume that technical or lowstatus work gets done 'automatically', as if people were programmable devices" ([37], p. 131). In this text, we claim that the context of agile work can likewise benefit from a perspective that illuminates the often taken-for-granted background work, which plays a crucial role in enacting and keeping up with agile workplaces. Even though agile work is often identified as intellectual work done by high-status technology developers [38], we argue that these developers are, nevertheless, also affected by forms of deletions and, consequently, compelled to care for the enactment of the seemingly universal and easily applicable agile work methods.

\section{Matters of Care and Affective Work}

Puig de la Bellacasa states that caring is often charged with uncomfortable affects of "anxiety, sorrow and grief" ([28], p. 212). We use affects $^{6}$ as an analytical approach, looking at the emotions and bodily exhaustions of our research partners to grasp what they care

\footnotetext{
${ }^{6}$ We use the terms affect and emotion interchangeably according to Sara Ahmed's claim that affect and emotion signify the same. Following her, an "analytic distinction between affect and emotions risks cutting emotions off from the lived experiences of being and having a body" ([39], p. 39) on the one hand. On the other, a distinction risks the assumption that emotions come from within individual bodies (Ahmed interviewed in [40], p. 97; [41], p. 117). Therefore, affect/emotion stand for
}

about and what cares for them. The focus on affects at the workplace leads us to the spheres of feminist STS, sociology, and geography of work. These research perspectives point to the role of emotional practices and advocate a shift from a general and detached approach toward labor to a closer examination of a workplace, its identities, bodies, and emotions [43-45]. Accordingly, embodied practices of knowledge production are researched to target the undertheorized areas of affect and intimacy within scientific work [46]. Against this background, Pfeiffer criticizes the one-sidedness of researching only visions connected to new work paradigms because they "will not unfold in discourse alone; [they] will take place — or not — on the shop floor and be created and put to work by real people and their living laboring capacity $[\ldots]$, within real labor relations, using and creating real technology in all its sociomateriality" ([52], p. 120) ${ }^{7}$. Thus, transferring Puig de la Bellacasa's lens of "matters of care" into the context of agile work guides us to the affective care work that upholds the sociotechnical assemblage of agile work within capitalistic entanglements of "labor process[es] and accompanying embodied skills, technologies, machines and materials" ([53], p. 82).

\section{Working Agile as a Matter of Care}

As illustrated above, researching affective care work in specifically agile workplaces of technology development is important to grasp invisibilized labors, yet it remains under-researched. According to Moore, "the agility system is a new frontier for prescribing externalized quantification of labour and ascribing (under)value to affective labour" ([21], p. 50). Although Moore raises critical awareness about the affective aspects of agile work, her analysis is limited to agility as a tracking device that increases control and surveillance over labor processes. We

Footnote 6 (continued)

both - the emotional dimension of daily life as well as the discursive dimension, power-laden structures and representations ([42], p. 94).

7 Several scholars claim that the global discourses on innovation and making subjectify people into entrepreneurial citizens. They demonstrate how the visions, desires, hopes - the utopian language of science, technology and innovation narratives in general - have crucial effects on industrial companies, labour processes and on the employees themselves [47-51]. 
seek to extend studies on agile work by critically engaging with the often-dismissed practices taking place in the background during agile work processes. Only by looking at background work that we define as caring practices embedded in agile work methods are we able to demystify the dominant beliefs in flexibility, co-working, and rapid prototyping once these methods are implemented in the workplace. Our analysis extends the perspective with a closer look at power politics and especially the emancipatory potential that the visibilized caring relationships might entail. The aim, therefore, is to re-present taken-for-granted facts in a more careful way in order to outline their fragility that needs to be taken care of.

\section{Caring for Enacting Agile Work}

The following empirical analyses are based on ethnographic research [54] conducted in a Kenyan makerspace and in three German industrial companies. We conducted interviews with technology developers, managers, interns, and freelancers who are involved in the agile development of new technology. For several months, we engaged in "working participant observation" [55] at makerspaces and in the development departments of industrial companies. The analysis of our empirical data is based on qualitative content analysis [56] and situational analysis [57]. Drawing on these empirical examples, we show that agile work as a "matter of fact" needs care to become a stable and universally applicable work practice. Therefore, our goal is to understand what practices are necessary to actually work agile, on the assumption that merely introducing agile work methods into workplaces will not automatically lead to greater flexibility and innovativeness.

The aim of agile work, as articulated in the Agile Manifesto [7], is to replace a too narrowly structured work organization with a more adaptive, flexible, and spontaneous work process. Methods and tools such as the so-called Scrum Board (Fig. 1), co-working facilities, and rapid prototyping machines are claimed to be the facilitators of this endeavor.

To work agile during the development of technology means that the innovation process is structured in a highly iterative way: The generation of an idea, building its prototype, testing it, and using the feedback to think over the previous idea is a dynamic work cycle that goes

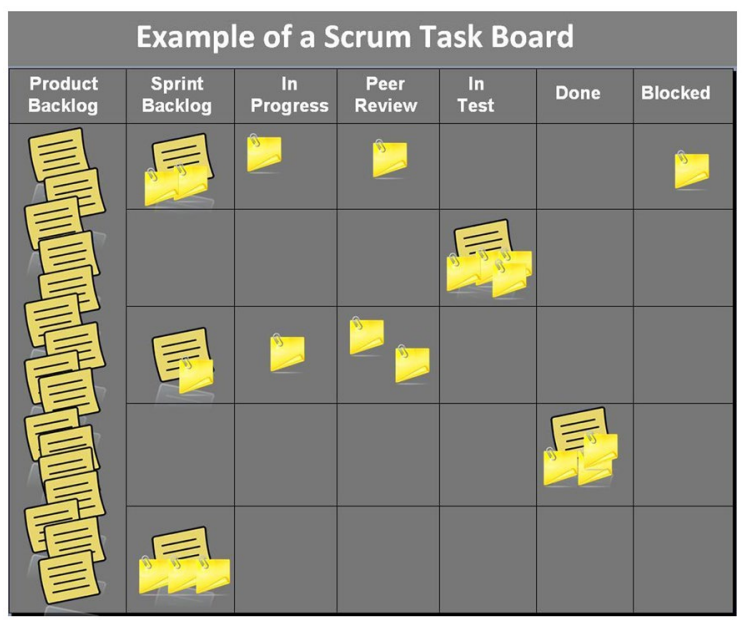

Fig. 1 The Scrum Board is utilized to organize and distribute work tasks. https://commons.wikimedia.org/wiki/File:Scrum_ task_board_example.jpg. Accessed 29 February 2020

back and forth between the different steps. To help agile workers not to get lost in the flexible work process, the Scrum Board unifies every work task documented on transferable Post-its to organize and prioritize what to do (next). Additionally, co-working practices such as brainstorming sessions and shared work desks should support the non-hierarchical and interdisciplinary exchange of thoughts to achieve innovative ideas. To include the prospective users of a technology right at the beginning of the development process, specific machines, digital tools, and materials are provided to rapidly build the first testable prototype of an idea.

In the following, we trace the actors' care work to address what practices are needed to actually work agile. In the first part, we show that caring for the enactment of flexibility requires care through sociotechnical relationships. Second, we exemplify the affectiveness of agile work by drawing on emotional and bodily practices to make co-working possible. Third, we claim that agile work is always situated by showing the context specificities of making prototyping possible. Although the sociotechnical, affective, and situated nature of agile work is exemplified separately by giving different examples of caring for agile work, the characteristics discussed in the following count for agile work in general. All in all, the presented empirical data shed light on the complex sociotechnical caring relationships that are usually transferred into the background of accounts on technology development work. As we conclude, these 
invisiblizations are grounded in hierarchies of differently valued skills, through which power asymmetries get (re-)established.

\section{Scrum Boards and the Making of Flexibility}

Compared with "traditional" workplaces with fixed schedules and meetings planned well in advance, work at makerspaces and other agile workplaces is expected to lead to more flexible and adaptive work episodes. Materials such as 3D printers, computer software, Post-its, or whiteboards take over the task to maneuver technology developers "out of stuck thinking patterns" (Interviewee 1), as an agile coach emphasizes. Due to the highly iterative design process involved in generating an idea, testing its prototype, and constantly rebuilding it, it is hard to keep track of the almost daily changing work foci during technology development. Therefore, agile work draws on the Scrum Board (Fig. 1) as a device to make work tasks transparent and comprehensible for every actor involved. The Scrum Board fulfills its purpose of work flexibilization by constantly being fed Post-its that contain the work tasks that are still in progress, those completed, and those that need to be postponed. The challenge of how to prioritize and bring structure into work life is, thus, intended to be solved by the Scrum Board's responsibility to quickly reorder work tasks and consequently react to alterations.

Against this background, most of our interviewees highlight the importance of Post-its, whiteboards, and pins that make it possible to prioritize and order their work: "So, first of all you stick a Post-it on the Scrum Board and say: 'You have to do that, you have to do that, you have to do that'. [...] And then the tasks are simply defined and weighted with points." (Interviewee 2). As another interviewed technology developer mentions, the process of prioritizing is particularly enabled by the materials that allow them to do so: "ideas and decision-making can only be realized with the tools" (Interviewee 3). These existential materials are highly visible and well-recognized (if not fetishized) things when being treated as instrumental, functional tools that help to be(come) agile. Yet, the processes of ideation or dividing up tasksand thus, more adaptive and flexible work practices - are highly dependent on the close sociotechnical relationships between technology developers and materiality such as whiteboards and Post-its. That means, although the non-human instrumentalist role in enacting agile work is acknowledged, technology developers and Post-its or Scrum Boards are hardly ever recognized as equally active agents within their close relationships.

Additionally, tasks such as those of the so-called Scrum Master are essential for the enactment of flexibility and agility, yet the Scrum Master's caring for them is often invisible when being taken for granted. Scrum Masters are responsible for the progress of their team and thus for ensuring the establishment of a flexible and smooth working process. Regardless of the distinctive title "Master," the Scrum Masters' role is often regarded as equivalent to that of the other agile team members, even though they are confronted with a lot of work and responsibilities that the others do not have to care about. As one of the interviewed Scrum Masters notes, he is responsible for putting up and reorganizing Post-its on the Scrum Board, work tasks that nobody recognizes as they are assumed to be mundane: "for some people it looks banal, but I think there is a lot behind it" (Interviewee 4). In addition, the task of updating the Scrum Board is mainly claimed to be not worth mentioning; however, most employees we talked to are confronted with the difficulty of updating it on a regular basis: "You may think: let's forget about the Scrum Board; I'll put up the Post-its on another day. And then afterwards you'll think: 'Okay, I made a mistake this week. My work was total nonsense"" (Interviewee 5).

The taken-for-granted practice of shuffling Postits to update the Scrum Board plays an essential role in producing flexibility while guaranteeing that all work tasks will be accomplished. Hence, caring for a Scrum Board demonstrates that the implementation of flexibility does not only need a tool like a Scrum Board but also involves caring practices by social and technical actors to enact and maintain agile work. It becomes clear that the benefits of agile work, like the flexibility and transparency of work, are precarious elements that are constantly in need of care and stabilization.

\section{Affective Bodies and the Making of Co-working}

In addition to the necessity of entering sociotechnical relationships to care for the agile work assemblage, our analysis demonstrates that highly bodily and affective tasks are required to establish agile methods such as co-working. 
Technology developers should benefit from coworking with their colleagues through connecting various expertise and interdisciplinary knowledge in a non-hierarchical manner. Regular meetings, workshops, co-working spaces, or shifting work desks bring different stakeholders together to gain insights into "the other side" of the work process, as an agile team member indicates: "How does it for example look like on the engineers' side?" (Interviewee 2). Co-working on an emerging technology should generate brainstorming sessions that create more outstanding ideas and, thus, progressive innovations.

Nevertheless, our research insights show that collaborative work is only possible because of the physical and emotional presence of working bodies: "Every project requires attention. Every project wants me physically present in the team" (Interviewee 6). The agile worker's notion of "physical presence" strongly indicates that the bodily and affective efforts are a vital part of collaborative teams. One agile engineer gives the following outline:

I'm not a superwoman, [...] sometimes I feel like I have to be everywhere: Downstairs I have to talk to contractors, at the same time upstairs I have to talk to interns to encourage them. [...] You are kept on toes, you are kept to read, you are kept to work, you are kept to walk and at the end you should come up with ideas. (Interviewee 7)

Dealing with the concerns of colleagues and other partners during meetings and bilateral consultations is part of the daily agenda of technology developers. Hence, keeping up with the collaborative workflow, the bodily task of constantly walking from one team member to the other is a necessary one. Another agile worker stresses, in a similar manner, how he moves around all day: "So, it's really a rarity that I'm at my workplace, which is right here in this room. I run around all day and try to understand a lot of things" (Interviewee 8). Besides intellectual activities like "understanding a lot"-which are perceived as obvious skills of technology developers and designers - physical endurance is also required for ensuring an agile co-working environment. "Running around" and "being kept on toes" are bodily efforts necessary to fulfill co-working requirements; another would be the affective work of "encouraging" (see above) and showing patience and empathy toward co-workers: "How do I pick up the [others'] concerns? How do I know about my colleagues' issues?" (Interviewee 2) are questions that agile workers (have to) care about. The affective practice of discussing in order to co-work is foremost problematized as time-consuming and unproductive by our research partners: "The biggest problems are discussions. You just talk yourself to death" (Interviewee 8).

While co-working is often regarded as an element of agile work that is carried out without much strain, we observe that caring for co-working has perceptible bodily effects. Such activities as approaching several actors, talking and negotiating with them, and brainstorming about a specific challenge are bodily exhaustions that require emotional sensitivity. Thus, besides the sociotechnical aspect of agile work when caring with the Scrum Board, the care for establishing co-working shows the embodied and affective state of working agile. Again, our research insights reveal that agile work cannot be understood as a simple applicable tool but, instead, as something that needs care and physical and emotional strength to be established.

Acquisition of Components and the Making of Prototypes

Besides making work more flexible and collaborative, agile work also contains the method of rapid prototyping, which means building prototypes very early in the development process of a technology in order to amplify efficiency. The prototypes allow developers "to fail early and often" ([58], p. 6), meaning to regularly test prototypes to iteratively rebuild, enhance, or destroy them based on the gathered (user) feedback. Nevertheless, some aspects about rapid prototyping are left out from discourses on agility, namely, that the materiality of prototypes entails the need for specific resources to build them. Therefore, we argue that making prototyping possible is dependent on background work in the form of caring practices that are context-specific and contingent on where agile work is implemented.

During our research, the background work for enacting agile work became particularly visible in the care for acquiring components to prototype: Lists are made in preparation for a well-planned and structured prototyping process. These lists usually enumerate the equipment that is needed for realizing a prototype: "The challenges went to the deep details of component selection. Basically, the design consists of selecting components, coming up with a list of those and getting them" (Interviewee 9). As the interviewee states, the 
component lists are the basis for the laborious research on where to obtain the needed material. Thus, every written document on technology development is not only intended to share open-source knowledge about necessary components but also to include a list of where to get them so that other people can rebuild the projects easily (Research Diary July 2016). The procurement of material is so important that it is included in the daily morning routine of the mechanical lead at a Kenyan makerspace:

In the morning, I have to plan the day. After putting up the schedule of who is doing what for the day, I need to know the materials. How will they get to the workshop? How will the process go smoothly? There have to be materials, so there has to be a plan. (Interviewee 7)

The design and manufacturing of a prototypeand, thus, the possibility to actually work agilebegins right at the production of precisely these lists documenting the necessary materials. Not only is the strenuous work of planning where to get the required material set into the background of rapid prototyping work but so is the mundane and time-consuming task of buying the essential components in specialized shops or online markets.

In particular, when comparing the efforts of technology developers in Kenya with those of developers at other places of innovation, we are confronted with very situated and context-specific practices: Kenyan developers are faced with a different level of access to prototyping components than their American counterparts, for example, where procurement is "easy" as "you can simply order components from online distributors much like you'd buy a product from any online store. Individual prices tend to be low and parts arrive quickly, with familiar shipping options" ([59], p. 54). By contrast, Kenyan technology developers are not awash in abundant resources because high taxes on imported goods lead to difficulties in acquiring resources and tools to prototype [60]. These circumstances lead to the careful engagement with prototyping material once acquired, meaning that everyone is careful not to waste resources during the act of prototyping. Consequently, our research partners put time and effort into calculating every step of the prototyping process, such as drawing models or writing lists and Excel sheets, to build a highly "polished prototype" instead of one that is held together with "duct tape" (Interviewee 10). Attempts are made to circumvent the rapid prototyping mantra "to fail early and often" by all means through an efficient design process that pursues control over the development process in general and the management of resources in particu$\operatorname{lar}$ ([61], p. 1012). These forms of "calculative making" [62] are a result of caring for prototypes in a context of scarce resources ${ }^{8}$.

Illuminating the background work of prototyping, namely, the acquisition of components and tools, exemplifies the situatedness of agile work. The care efforts to make agile work possible depend on the context specificities such as the availability of components and other prototyping material. Thus, enacting agile work through rapid prototyping is a more challenging and precarious endeavor for technology developers in Kenya than for workers in "places of abundance" such as German industrial companies.

\section{Power Asymmetries Through In/Visibilized Work}

"The politics of caring have been at the heart of concerns with exclusions and critiques of power dynamics in stratified worlds" ([24], p. 86).

The empirical examples given show that sociotechnical, affective, and situated care is invested in the enactment of agile work such as the promises of flexibility, interdisciplinary co-working, and iterative rapid prototyping. The practices of shuffling Post-its, running around to talk to colleagues, and the preparation of prototypes are often felt to be difficult and highly challenging tasks to fulfill. Even though care work is an exhausting daily task that enacts and stabilizes agile work as a "matter of fact", it usually occurs in the background of technology development work. It seems that these vital work practices get relegated if not deleted due to their characteristics of mundaneness and ordinariness. Therefore, we argue that care work is embedded in power asymmetries, which we characterize according to hierarchies of skills when

\footnotetext{
$\overline{8}$ To grasp the situatedness of making technologies especially outside the usual centers of innovation, Ames et al. use the lens of "making do" to see "the pragmatic situatedness within the constraints of everyday life, where creativity and innovation rub against precarity and marginalization" ([63], p. 2).
} 
becoming differently in/visibilized in the daily life of agile actors.

Neither in German industrial companies nor in Kenyan makerspaces could we observe agility fulfill its promise to break with hierarchies in the workplace. Even though every single actor in the sociotechnical assemblage of agile work is dependent on every other actor's role, only specific skills are valued and acknowledged when becoming visibilized, for instance, on the Scrum Board. Tasks shown on the Scrum Board are often personalized because they refer to the team members' disciplinary backgrounds, expertises, and organizational positions: "It is always the case that there is someone who is specialized in one topic, [...] and that's what's required for the task" (Interviewee 11), one technology developer clarifies. Hence, the distribution and visibility of tasks are closely connected to specific skills and the availability of developers providing such required competence. Consequently, some people, things, and tasks appear on the Scrum Board, and some do not. In this sense, agile work methods (re-)establish hierarchies of skill between those that get acknowledged and visibly valued on the Scrum Board and those practices that seem mundane and not worthy of their own Post-it. For instance, the bodily work that human actors exercise in their daily life, the Scrum Master's task of updating the Scrum Board, or making lists as the preparation for developing a prototype are not included on the Scrum Board.

When the great number of handbooks advertising agile work is considered, tasks worth posting on the Scrum Board are only ones that "provide the greatest value and ROI (return of investment) to the organization" ([64], p. 18). As a result, many essential daily practices are not part of the visibilized tasks as they are not understood as serving the organization's targets. Jeff Sutherland, who is a strong proponent of agile work, exemplifies which tasks are not worthy of being visibilized: "cleaning the shop floor, daily machine maintenance, or refactoring code," tasks that "are so routine that they are not even explicit in the work plan" ([65], p. 712). Hence, mundane activities are not valued as specialized skills or core qualifications of a technology developer, although they represent important competencies to enact agility in the first place.
Overall, power asymmetries become visible when we look at the taken-for-granted, devalued, nonstandardizable care practices in the context of agile work. Essential tasks and responsibilities are acknowledged in a highly unequal manner: Some work is acknowledged and highly valued, while some activities are turned into a common, taken-for-granted thing or practice-yet all of them are vital for making agile work happen. Those caring practices are essential work activities that contribute to the general value creation of an organization but nevertheless remain unacknowledged. Making these imbalances between more and less valued work activities visible shows that power asymmetries are established along hierarchies of "valuable" skills. Thus, we are finally directed toward the valuation systems within technology development: With a particular orientation to capitalist rationales, visible work practices mainly represent objectives such as the obvious creation of value through investments and increased efficiency and rationality $[64,65]$.

\section{Emancipatory Caring Relationships}

Our analyses have made visible the care practices of enacting and maintaining agile work, and we have highlighted the rather unexpected existence of care work in contexts of paid and formalized technology development. We also showed how invisible care work is characterized by power asymmetries. However, we do not want to end the paper with only criticizing forms of domination by showing that care is exhausting, yet unvalued work. Making invisibilized care work visible is indeed an important step in criticizing inequalities within capitalist understandings of work and value creation. However, often scholars do not give any hints of how to change the problematized circumstances. For example, Pinel et al.'s [35] insightful research about the care for data within science ends with the authors' problematization of neglecting care. They also stress that the current valuation system of universities does not recognize the affective care work for data, although it generates value for the respective research department ([35], pp. 18-19). Nevertheless, further elaborations on how this form of power could be altered or transformed into liberating forces remain unmentioned. This is quite surprising given 
that Puig de la Bellacasa emphasizes that care is "a speculative commitment to think about how things would be different if they generated care" ([24], p. 96). Therefore, we hereinafter speculate how a care perspective may also carry emancipatory potential.

What would happen if we do not see care in terms of exploitative dependencies and hierarchies but as an essential part of life? Feminist scholars and activists demand a shift in everyone's (especially nonindigenous) worldview toward an inclusive, solidary care community instead of self-determined, rationalized working bodies that are voiceless and powerless in the current capitalist mode of production [66-68]. Lorey [69] refers to the Spanish women's collective Precarias a la deriva [70] and offers the following explanation:

It is not a matter of demonizing autonomy and freedom, but rather of rethinking them from the perspective of mutual solidarity, affection and affinity. For the lines between those who care and those who receive solidarity and support cannot be clearly drawn if they are perceived as reciprocal, infinitely indebted care relationships ([69], p. 13).

Seen from this perspective, we imagine care neither as a hierarchical act whereby someone/something resilient cares for someone or something vulnerable nor as work that is deleted through hierarchical valuations. Instead, a care perspective acknowledges the interdependencies that all life is based on without relating them only to dynamics of power and oppression. By rejecting dependency as a form of universal domination, "we are able to identify forms of social action that cannot be explained within a framework of domination, such as solidarity [and] mutual support" ([71], p. 7), as Meyer et al. discuss in their study on the emancipatory potential of industrial production.

In line with these thoughts, the awareness that everyone and everything is doing care work and is simultaneously in need of care carries the potential for emancipation from capitalist valuations such as efficiency, rationality, and productivity. Interrelationships that would usually be conceived of as unequal and asymmetrical (for instance, between those enjoying a hot bath and those, namely, the water maintenance actors, who make sure that water is running [34]) may be substituted for a more symmetrical awareness of co-dependence. Thus, and referring to
Haraway, caring may imply the opposition of strong dualisms that "have all been systemic to the logics and practices of domination of women, people of color, nature, workers, animals - in short, domination of all constituted as others" ([72], p. 177). Our understanding of care, therefore, unsettles dichotomies and restrains us from the distinction between "us" and "others" as we are all part of and contribute to sociotechnical networks. We argue that in order to emancipate ourselves from power relations that become established through hierarchies of skill, we have to acknowledge that humans coexist with nonhumans (be they technical or organic) in which everyone and everything depends on the care of others.

Transferring the ubiquity and necessity of care to the agile work assemblage, we understand the caring relationships between technology developers, whiteboards, Post-its, co-workers, body strengths, Excel sheets, and prototyping components not only as embedded in oppressive power asymmetries but also as a sociotechnical, affective, and situated network of human and nonhuman actors caring for each other. In both our case studies, technology developers put a lot of care into selecting different materials for rapid prototyping, continuously refining their prototypes and treating machines with great respect. Thus, machines are often stroked, and tools, sketches, and even scribbles are often treated as precious things to store (Research Diary April 2019). Lists are an important companion by which technology developers organize their daily life, and the workplace's architecture of co-working desks or whiteboards also establish spaces for protection and intimacy (Research Diary March 2017). These affective sociotechnical relationships cumulate in emotions such as "love" when technology developers emphasize the loveable support of machines, but also when they call their prototype "their baby" (Research Diary November 2017).

Humans who give birth to technologies [73] and technologies that support and protect humans [34] illuminate care practices that exceed a humanist understanding of care. Regarding nonhumans as protective agents that care for humans may lead to a more respectful understanding of prevailing dependencies. As Buser and Boyer underline, "air quality monitors protected workers' lungs from noxious gases underground and hardhats protected heads" ([34], p. 84). Thus, paying closer attention to the collaborations between Scrum Boards, Postits, pens, cardboards, computers, desks, Scrum Masters, 
team members, and cleaners leads us to a different understanding of dependencies, which does not value a particular type of work over others. The different skills, competencies, and existences would be treated as all playing an equal role in well-being. Transferring care to the study of emancipation may finally acknowledge the fundamental sharing of all responsibilities within every aspect of life, including knowledge work, and dreams of work that do not standardize and quantify but "forg[es] bonds and attachments" ([33], p. 16). Hence, attaching care to contexts loaded with power, control, and domination provides new ways of understanding the fragility of universal facts and directs our attention to dynamics of co-living - and working - other than oppression. This care perspective raises awareness of the solidary network of sociotechnical living and may pave the way to emancipation from prevailing unequal valuations of work.

\section{Concluding Remarks: Careful Emancipatory Technology Studies}

Throughout this paper, we have argued that much caring for enacting and stabilizing agility is required to keep up with the current imperative of agile work. Revealing the taken-for-granted work occurring in the background pointed us in the direction of the caring sociotechnical relationships that are vital for working agile. Our analysis has thereby moved away from treating agile work as a "matter of fact"- that is, a universally applicable tool that always has the same outcome, be it flexibility or domination. Instead, we have outlined the fragility and subtlety of agile work practices that continually need to be taken care of. Hence, we have shown how the everyday work of enacting the promises of flexibilization, co-working, and rapid prototyping is contingent on the challenging sociotechnical, affective, and situated care practices. As a result, our investigation has visibilized work that is often dismissed and disregarded yet so essential to agile capitalist workplaces. Thus, introducing and establishing agile work necessitates careful practices and cannot be regarded as a simple, linear, and universally applicable process but as a precarious and fragile matter of care. In this regard, we have discussed the power dynamics underlying the invisibilization of care work and have pointed to hierarchies of valuing skills and qualification differently.

In conclusion, we call for careful Emancipatory Technology Studies (ETS) that further speculate how an emancipatory world would look if care is acknowledged in terms of sociotechnical, affective, and situated relationships forming the base of life. Careful ETS should render those sociotechnical practices visible that occur in the background, and detect hierarchies between, for instance, valued and non-valued work or responsibilities (between human and nonhuman actors) to shed light on current valuation systems in technology development. Therefore, and most importantly, ETS can initiate nuanced explanations for prevailing precarity and illuminate potentials for a better life embedded in caring relationships. This perspective may give us new inspiration for the sociotechnical relationships that make up our life by re-configuring our understanding of dependency in a caring and supporting manner. Consequently, analyzing emancipation in the context of technology development should imply a very careful and situated approach, by which both-researchers and research subjects-attend to the manifold concerns, cares, and sorrows that are evoked by powerful deletions of work.

Acknowledgements We would like to thank our research partners who offered us their precious knowledge and time to make this research possible. We also want to thank the two anonymous reviewers, our colleagues, and friends whose valuable criticism and feedback helped to strengthen the article's argument.

Author Contribution All authors contributed equally to the study conception and design. Material preparation, data collection, and analysis were performed by Klara-Aylin Wenten and Alev Coban. The first draft of the manuscript was written by Klara-Aylin Wenten and Alev Coban, and all authors commented on previous versions of the manuscript. All authors read and approved the final manuscript.

Funding Open Access funding enabled and organized by Projekt DEAL. The research of one of the authors is supported by the Hans-Böckler-Stiftung.

\section{Declarations}

Conflict of Interest The authors declare that they have no conflict of interest.

Open Access This article is licensed under a Creative Commons Attribution 4.0 International License, which permits use, sharing, adaptation, distribution and reproduction in any 
medium or format, as long as you give appropriate credit to the original author(s) and the source, provide a link to the Creative Commons licence, and indicate if changes were made. The images or other third party material in this article are included in the article's Creative Commons licence, unless indicated otherwise in a credit line to the material. If material is not included in the article's Creative Commons licence and your intended use is not permitted by statutory regulation or exceeds the permitted use, you will need to obtain permission directly from the copyright holder. To view a copy of this licence, visit http://creativecommons.org/licenses/by/4.0/.

\section{References}

1. Harris R (2015) The changing nature of the workplace and the future of office space. J Prop Invest Financ 33(5):424435. https://doi.org/10.1108/JPIF-05-2015-0029

2. Bouncken RB, Reuschl AJ (2016) Coworking-spaces: How a phenomenon of the sharing economy builds a novel trend for the workplace and for entrepreneurship. Rev Manag Sci 12(1):317-334. https://doi.org/10.1007/ s11846-016-0215-y

3. Tanvir S, Safdar M, Tufail H, Qamar U (2017) Merging prototyping with agile software development methodology. Circulation in Computer Science. Int Confr Eng Comput Info Technol 50-54

4. Kelliher C, Anderson D (2010) Doing more with less? Flexible working practices and the intensification of work. Hum Relat 63(1):83-106. https://doi.org/10.1177/ 0018726709349199

5. Böhmer A, Beckmann A, Lindemann U (2015) Open innovation ecosystem: Makerspaces within an agile innovation process. Paper Presented at the ISPIM Innovation Summit, Brisbane, Australia

6. Bergweiler G, Hansen J, Dörfer M (2019) Agile development with physical prototypes for a better project planning. ATZ Worldw 121:44-47. https://doi.org/10.1007/ s38311-019-0075-6

7. Beedle M, van Bennekum A, Cockburn A, Cunningham W, Fowler M, Highsmith J, Hunt A, Jeffries R, Kern J, Marick B, Martin R, Schwaber K, Sutherland J, Thomas D (2001) The agile manifesto. https://agilemanifesto.org. Accessed 28 Feb 2020

8. Gillies D (2011) Agile bodies: A new imperative in neoliberal governance. J High Educ Policy Manag 26:207-223. https://doi.org/10.1080/02680939.2010.508177

9. UK Government Service Manual (2020) Agile delivery. How to work in an agile way: Principles, tools and governance. www.gov.uk/service-manual/agile-delivery. Accessed 28 Feb 2020

10. Deloitte Center for Government Insights (2017) Agile in government. A playbook from the Deloitte Center for Government Insights. www.deloitte.com/content/dam/ insights/us/articles/3897_Agile-in-government/DUP_ Agile-in-Government-series.pdf. Accessed 28 Feb 2020

11. Joroff ML, Porter WL, Feinberg B, Kukla C (2003) The agile workplace. Journal of Corporate Real Estate 5(4):293-311. https://doi.org/10.1108/14630010310812145
12. Turner F (2006) From counterculture to cyberculture: Stewart Brand, the Whole Earth Network, and the rise of digital utopianism. University of Chicago Press, Chicago

13. Söderberg J, Delfanti A (2015) Hacking hacked!: The life cycles of digital innovation. Sci Technol Human Values 40(5):793-798. https://doi.org/10.1177/0162243915595091

14. Drewlani T, Seibt D (2018) Configuring the independent developer. Journal of Peer Production 12:96-114

15. Wenten KA (2019) Controlling labor in makeathons. On the recuperation of emancipation in industrial labor processes. In: Meyer U, Schaupp S, Seibt D (eds) Digitalization in industry. Between emancipation and domination, Palgrave McMillan, London, pp 153-177

16. Dickel S, Schneider C, Thiem C, Wenten KA (2019) Engineering publics: The different modes of civic technoscience. Sci Technol Stud 32(2):8-23. https://doi.org/ $10.23987 /$ sts.59587

17. Irani L (2015) Hackathons and the making of entrepreneurial citizenship. Sci Technol Human Values 40(5):799-824. https://doi.org/10.1177/0162243915578486

18. Lindtner S, Hertz G, Dourish P (2014) Emerging sites of HCI innovation: Hackerspaces, hardware startups \& incubators. CHI 2014. https://doi.org/10.1145/2556288. 2557132

19. Suchman L (2000) Making a case: 'Knowledge' and 'routine' work in document production. In: Luff P, Hindmarsh $\mathrm{J}$, Heath C (eds) Recovering work practice and informing system design, Cambridge University Press, Cambridge, pp 86-91. https://doi.org/10.1017/CBO9780511628122.003

20. Chan AS (2013) Networking peripheries-technological futures and the myth of digital universalism. MIT Press, Cambridge, London

21. Moore P (2018) Tracking affective labour for agility in the quantified workplace. Body Soc 24(3):39-67. https:// doi.org/10.1177/1357034X18775203

22. Hodgson D, Briand L (2013) Controlling the uncontrollable: 'Agile' teams and illusions of autonomy in creative work. Work Employ Soc 27(2):308-325. https://doi. org/10.1177/0950017012460315

23. Roth WM, Jornet A (2018) From object-oriented to fluid ontology: A case study of the materiality of design work in agile software development. Comput Support Coop Work 27:37-75. https://doi.org/10.1007/ s10606-017-9297-6

24. Puig de la Bellacasa M (2011) Matters of care in technoscience: Assembling neglected things. Soc Stud Sci 41(1):85-106. https://doi.org/10.1177/0306312710380301

25. Latour B (2005a) Reassembling the social. Oxford University Press, Oxford

26. Latour B (2004) Why has critique run out of steam? From matters of fact to matters of concern. Crit Inqu $30(2): 225-248$

27. Latour B (2005b) From Realpolitik to Dingpolitik or how to make things public. In: Latour B, Weibel P (eds) Making things public: Atmospheres of democracy. MIT Press, Cambridge, pp 14-43

28. Puig de la Bellacasa M (2012) 'Nothing comes without its world': Thinking with care. The Sociol Rev 60(2):197216. https://doi.org/10.1111/j.1467-954X.2012.02070.x 
29. Dalla Costa M, James S (1972) The power of women and the subversion of the community. Falling Wall Press, Bristol

30. Federici S (2012) Revolution at point zero: Housework, reproduction, and feminist struggle. PM Press, Oakland

31. Martin A, Myers N, Viseu A (2015) The politics of care in technoscience. Soc Stud Sci 45(5):625-641. https://doi. org/10.1177/0306312715602073

32. Jack M, Jackson S (2016) Logistics as care and control: An investigation into the UNICEF supply division. Proceedings of the 2016 Conference on Human Factors in Computing Systems: 2209-2219. https://doi.org/10.1145/2858036.2858503

33. Kocksch L, Korn M, Poller A, Wagenknecht S (2018) Caring for IT security: Accountabilities, moralities, and oscillations in IT security practices. Proceedings of the ACM on Human-Computer Interaction 2, Comput Support Coop Work 92:1-92:20. https://doi.org/10.1145/3274361

34. Buser M, Boyer K (2021) Care goes underground: Thinking through relations of care in the maintenance and repair of urban water infrastructures. Cult Geogr 28(1):73-90. https://doi.org/10.1177/1474474020942796

35. Pinel C, Prainsack B, McKevitt C (2020) Caring for data: Value creation in a data-intensive research laboratory. Soc Stud Sci 50(2):175-197. https://doi.org/10. $1177 / 0306312720906567$

36. Star SS, Strauss A (1999) Layers of silence, arenas of voice: The ecology of visible and invisible work. Comput Support Coop Work 8(1-2):9-30. https://doi.org/10. 1023/A:1008651105359

37. Law J (1994) Organizing modernity. Blackwell, Oxford, Cambridge

38. Boes A, Kämpf T, Langes B, Lühr T (2017) The disruptive power of digital transformation. New forms of industrialising knowledge work. In: Briken K, Chillas S, Krzywdzinski M, Marks A (eds) The new digital workplace: How new technologies revolutionise work. Palgrave, London, pp 153-173

39. Ahmed S (2004) Collective feelings - Or, the impressions left by others. Theory Cult Soc 21(2):25-42. https://doi. org/10.1177/0263276404042133

40. Ahmed S, Schmitz SS (2014) Affect/Emotion: Orientation matters-a conversation between Sigrid Schmitz and Sara Ahmed. Freiburger Zeitschrift für GeschlechterStudien 20(2):97-108. https://doi.org/10.3224/fzg.v20i2.17137

41. Ahmed S (2004b) Affective economies. Social Text 79 22(2):117-139

42. Schurr C, Strüver A (2016) "The rest": Geographien des Alltäglichen zwischen Affekt, Emotion und Repräsentation. Geogr Helv 71:87-97. https://doi.org/10.5194/ gh-71-87-2016

43. Pfeiffer S (2019) From "in the wild" into the wilderness of field study approaches: The case of the company case study in german industrial sociology in times of digitalization. diGAP Working Paper 2019

44. McDowell L (2009) Working bodies: Interactive service employment and workplace identities. Wiley-Blackwell, West-Sussex

45. Carr C, Gibson C (2017) Animating geographies of making: Embodied slow scholarship for participant-researchers of maker cultures and material work. Geogr Compass 11(e12317):1-10. https://doi.org/10.1111/gec3.12317
46. Waldby C, Wakeford N, Green N (2006) Feminist technoscience: Intimacy, embodiment and abjection in science studies. Sci Stud 19(2):3-5. https://doi.org/10.23987/sts. 55191

47. Ames MG, Rosner DK, Erickson I (2015) Worship, faith, and evangelism: Religion as an ideological lens for engineering worlds. Proceedings of the 18th ACM Conference on Computer Supported Cooperative Work \& Social Computing 69-81. https://doi.org/10.1145/2675133.2675282

48. Avle S, Lindtner S, Williams K (2017) How methods make designers. Proceedings of the 2017 CHI Conference on Human Factors in Computing Systems:472-483. https:// doi.org/10.1145/3025453.3025864

49. Coban A (2018) Making hardware in Nairobi: Between revolutionary practices and restricting imaginations. Journal of Peer Production 12:60-76

50. Irani L (2015) Hackathons and the making of entrepreneurial citizenship. Sci Technol Human Values 40(5):799824. https://doi.org/10.1177/2F0162243915578486

51. Sivek SC (2011) "We need a showing of all hands": Technological utopianism in MAKE Magazine. J Commun Inq 35(3):187-209. https://doi.org/10.1177/0196859911410317

52. Pfeiffer S (2017) The vision of "Industrie 4.0" in the making - a case of future told, tamed, and traded. Nanoethics 11:107-121. https://doi.org/10.1007/s11569-016-0280-3

53. Gibson C (2016) Material inheritances: How place, materiality, and labor process underpin the path-dependent evolution of contemporary craft production. Econ Geogr 92(1):61-86. https://doi.org/10.1080/00130095.2015.1092211

54. Crang M, Cook I (2007) Doing ethnographies. SAGE Publications, London, Thousand Oaks, New Delhi

55. McMorran C (2012) Practising workplace geographies: Embodied labour as method in human geography. Area 44(4):489-495. https://doi.org/10.1111/j. 1475-4762.2012.01101.x

56. Mayring P (2010) Qualitative Inhaltsanalyse. Grundlagen und Techniken, Beltz, Weinheim, Basel

57. Clarke A, Friese C (2007) Grounded theorizing using situational analysis. In: Bryant A, Charmaz K (eds) The SAGE Handbook of Grounded Theory. SAGE Publications, Los Angeles, London, New Delhi, Singapore

58. Coughlan P, Fulton Suri J, Canales K (2007) Prototypes as (design) tools for behavioral and organizational change. J Appl Behav Sci 43(1):122-134. https://doi.org/10.1177/ 0021886306297722

59. Mellis DA (2011) Case studies in the digital fabrication of open-source consumer electronic products. Thesis submitted to the Program in Media Arts and Sciences School of Architecture and Planning in partial fulfillment of the requirements for the degree of Master of Science in Media Arts and Sciences at the Massachusetts Institute of Technology. https://alumni.media.mit.edu/ mellis/mellis-thesis-screen. pdf. Accessed 20 May 2019

60. Mungai C (2015) What's holding back Africa's tech startups? World Economic Forum. www.weforum.org/ agenda/2015/09/whats-holding-back-africas-tech-startups. Accessed 06 July 2017

61. Alexander JK (2009) The concept of efficiency: An historical analysis. In: Meijers A (ed) Philosophy of technology and engineering sciences. Elsevier, North Holland, pp $1007-1030$ 
62. Coban A (2019) Calculative making: The fear of failure in Kenya's Makerspaces. Backchannels - Blog of Society for Social Studies of Science. https://www.4sonline. org/calculative-making-the-fear-of-failure-in-kenyasmakerspaces/. Accessed 14 Jan 2021

63. Ames MG, Lindtner S, Bardzell S, Bardzell J, Nguyen L, Ahmed SI, Jahan N, Jackson SJ, Paul D (2018) Making or making do? Challenging the mythologies of making and hacking. Journal of Peer Production 12:1-21

64. Schwaber K (2004) Agile project management with Scrum. Microsoft Press, Redmond, Washington

65. Sutherland J (2019) A Scrum book: The spirit of the game. Pragmatic Bookshelf

66. Mol A, Moser I, Pol J (2015) Care in practice. On tinkering in clinics, homes and farms. Transcript, Bielefeld

67. Strang V (2017) The Gaia complex: Ethical challenges to an anthropocentric 'common future'. In: Brightman M, Lewis J (eds) The anthropology of sustainability. Palgrave Macmillan, New York, pp 207-228. https://doi.org/10.1057/978-1-13756636-2_12

68. Escobar A (2018) Designs for the pluriverse: Radical interdependence, autonomy, and the making of worlds. Duke University Press, Durham, London
69. Lorey I (2019) Emanzipation und Schulden. In: Lettow S, Maihofer A (eds) Demirović A. Emanzipation - Zur Geschichte und Aktualität eines politischen Begriffs. Westfälisches Dampfboot, Münster, pp 10-15

70. Precarias a la deriva (2014) "Was ist dein Streik?" - Militante Streifzüge durch die Kreisläufe der Prekarität. transversal texts, Wien

71. Meyer U, Schaupp S, Seibt D (2019) Digitalization in industry. Between domination and emancipation, Palgrave McMillan, London

72. Haraway D (1991) Simians, cyborgs, and women: The reinvention of nature. Routledge, London

73. Myers N (2008) Molecular embodiments and the bodywork of modeling in protein crystallography. Soc Stud of Sci 38(2):163-199. https://doi.org/10.1177/2F0306312707082969

Publisher's Note Springer Nature remains neutral with regard to jurisdictional claims in published maps and institutional affiliations. 